\title{
The Role and Teacher's Understanding in Implementing Curriculum on Vocational High School
}

\author{
Riana Nurmalasari, Blima Oktaviastuti, Annisau Nafiah \\ Universitas Negeri Malang \\ Universitas Tribhuwana Tunggadewi \\ Universitas Negeri Malang \\ E-mail address: riana.nurmalasari.ft@um.ac.id
}

\begin{abstract}
This study aims to describe the teacher's understanding and how teacher's role in the implementation of the 2013 curriculum. This research uses a descriptive qualitative research design with case study. Research data supported by research tools in the form of audio-visual and field notes. The informants are the headmaster, the vice minister of curriculum, teachers, and students who carry out learning using the 2013 curriculum at SMK 1 Kertosono. Based on the results of the analysis, it is known that the understanding of teachers is not so fully understood the 2013 curriculum as a whole. The role of teacher for implementation of the 2013 curriculum conducted by teachers including: (1) Planning, teachers in making learning plans based on the results of teacher group discussions conducted between teacher peers and the internet; (2) Implementation, the implementation of learning conducted by the teacher includes three activities, namely the introduction, main, and closing activities; and (3) Assessments, assessments made by teachers are authentic assessments, which include; assessment of attitudes, knowledge and skills.
\end{abstract}

Keywords: role, understanding, curriculum, teacher, vocational high school

One important factor for the progress of a nation is about education sector. The education sector has an important role in terms of preparing human resources (Wagiran, 2007). In line with this opinion, Wen (2003) states that human resources are the key determinant of the competitiveness of a nation. Therefore the government always continues to develop the education sector in various aspects, one of those is in the Vocational High School (SMK) (Nurmalasari, 2016). All efforts related to improve the quality $t$ in the education sector are carried out by the government in order to achieve quality education and be able to produce competent graduates. The efforts made by the government are to improve the curriculum. Efforts to improve the curriculum are closely related to the strategic role of the curriculum in the education sector (Soedijarto, 2004). The curriculum is part of the education and learning process (Sukmadinata, 2013). The curriculum itself is a plan, series, or arrangement of programs related to the learning process to achieve educational goals (Kwartolo, 2002; Munir, 2008; Hidayat, 2013; Sariono, 2014; Rohmanudin, 2014).
So it can be concluded that the curriculum is a guide to the learning process to achieve certain goals.

The government's effort in perfecting the curriculum is by replacing the Education Unit Level Curriculum (KTSP) into the 2013 curriculum. Hidayat (2013) states that in the 2013 curriculum the main point is the balance and enhancement of students' knowledge, attitudes, and skills. So that in the 2013 curriculum aspects outside of the cognitive are also highly considered. Oktaviastuti (2016) states that human behavior in daily life tends to be influenced by cognitive components. Furthermore, Oktaviastuti also stated that skills are also very important to be constantly developed especially in SMK. The strengths of the 2013 curriculum which are related to the scientific approach, the existence of competency approaches for certain fields, and character based (Mulyasa, 2013). With the 2013 curriculum, it is only as if the implementation was as it should be. In this case various parties contributed to the success or failure of the implementation of the 2013 curriculum. 
The application of the curriculum is closely related to the role of a teacher. This is because the teacher is one important factor in the implementation of all the designs in the curriculum that are realized in the learning process (Rohman, 2012). According to Sujati (2015) teachers are also an important aspect for the realization of quality learning. Especially if teachers have adequate competence, qualified teachers play an important role in the learning process (Nurmalasari, 2016). So in this case, the role of the teacher in implementing the 2013 curriculum is very necessary and sufficient to have a big impact.

\section{METHOD}

This research is a qualitative descriptive using case studies. Data collection was carried out at SMK 1 Kertosono with observation, interviews, and documentation. Sources of research respondents consisted of headmaster, teachers, and students. The method for checking the validity of the data is to use triangulation and re-observation, as well as the perseverance of researchers.

\section{RESULTS AND DISCUSSION}

\section{The Role of Teachers in Curriculum Implementation}

Based on the results of the study known that teachers conduct discussions among fellow teachers, especially teachers with the same subjects to make lesson plans so that they are synchronous. This activity is carried out routinely every semester. This is in line with the opinion of Partin (2009) and Sumarno (2014) that teachers are supposed to arrange the learning tools as fully and as well as possible so that the process of learning outcomes can be in accordance with the objectives. This is because learning activities will be more effective if the teacher arranges and determines the design of the learning process before the learning process takes place (Toth, 2012).

After developing the learning tools, the teacher must also be able to apply the results of the lesson plans in a real learning process. Based on the results of observations, interviews and direct observation it is known that teachers at SMKN 1 Kertosono use a variety of learning methods during learning activities. In this case the teacher acts as a facilitator during the learning process (Kosasih, 2014). The teacher also has a role to convey knowledge to students (Sanjaya, 2011). In this case the role of a good and right teacher is the ability to adjust the material to the needs of students and according to content standards (Sudjimat, 2014).

Furthermore, in terms of evaluation, based on the results of the study it was found that teachers at SMKN 1 Kertosono 1 used assessment techniques that were adapted to adjust the type of material being tested. In the 2013 curriculum the assessment system uses an authentic assessment system (Taufina, 2019). Some things that support the role of teachers in implementing the 2013 curriculum are the quality of learning tools that are prepared and used.

\section{Teacher's Understanding in the Implementation of Curriculum}

Based on the results of the study, it is known that in general teachers at SMKN 1 Kertosono do not really understand the contents of the 2013 curriculum, especially in the mechanical engineering expertise program, especially teachers who have not participated in vocational training / workshop in 2013 curriculum. It can be interpreted that with the concept of understanding that they have about the learning process in the mechanical engineering expertise program is still in the level of general knowledge from the results of the socialization carried out by the school, not yet focused on understanding. Mulyasa (2013) states that it takes time to fully understand new things, in this case the 2013 curriculum. One form of activities undertaken by teachers to support the success of the 2013 curriculum is to understand core competencies in relation to graduate competencies. A similar statement was also conveyed by Hurotul 'Aini (2014) stating that, the readiness of teachers in implementing the 2013 curriculum was not optimal.

\section{CONCLUSION}

Based on the results of the analysis of this research data, it is known that the understanding of vocational teachers is not so fully understood the 2013 curriculum as a whole. The role of teachers for implementation 2013 curriculum conducted by 
teachers including: (1) Planning, teachers in making learning plans based on the results of teacher group discussions conducted between teacher peers and the internet; (2) Implementation, implementation of learning conducted by the teacher includes three activities, namely the initial, core, and closing activities; and (3) Assessments, assessments made by teachers are authentic assessments, which include; assessment of attitudes, knowledge and skills.

\section{REFERENCES}

Hidayat, S. 2013. New Curriculum Development. Bandung: PT. Remaja Rosdakarya.

Hurotul 'Aini, Winda. 2014. Teacher Readiness in Applying the 2013 Curriculum to Economics Subjects in High School. Thesis not published: . Malang: PPS UM.

Kosasih, E. 2014. Learning Strategies and Learning Implementation of the 2013 Curriculum. Bandung: Yrama Widya.

Kwartolo, Yuli. 2002. Critical Notes on Curriculum Based Kompetensi. Jurnal Pendidikan Penabur. 1(1): 1-9.

Mulyasa, E. 2013. Development and Implementation of 2013 Curriculum. Bandung: Remaja Rosdakarya.

Nurmalasari, Riana; Puspitasari, Poppy; Mardji; Hartiningtyas, Lativa; Suswanto, Hary. 2016. The Role of Sarjana Mengajar's Teachers for Student's Outcomes on Vocational High School. AIP Conference Proceedings. 1778 (030042): 13.

Nurmalasari, Riana; Mardji; Andoko. 2016. Implikasi Program Sarjana Mengajar pada SMK di Jawa Timur. Jurnal Pendidikan, Teori, dan Pengembangan. 1(7): 1376-1382.

Oktaviastuti, B., Dardiri, A., dan Nindyawati. 2016. Improving Technical Skill of Vocational School Engineering Students Through the Implementation of Industrial Work Practices. Jurnal Pendidikan: Teori, Penelitian, dan Pengembangan. 1(4): 681-685.
Oktaviastuti, B., Dardiri, A., dan Nindyawati. 2016. The Correlation Between Industrial Support and Vocational Attitude Toward The Increasing of Student's Technical Skill on Building Drawings Engineering. AIP Conference Proceedings. $\underline{1778}$

Partin, R. 2009. The Classroom Teacher's Survival Guide (3th ed). San Fransisco: John Wiley\&Sons.

Rohman, M. 2012. Curriculum Character: Reflection and Proposal Solutions to KBK and KTSP. Jakarta: Prestasi Pustakaraya.

Rohmanudin. 2014. Teachers' Understanding of the 2013 Vocational Curriculum and its Implementation in the Vocational Mechanical Engineering Program. Thesis not published. Malang: UM.

Sariono. 2014. Curriculum 2013: Golden Generation Curriculum. Jurnal Dinas Pendidikan Kota Surabaya. 3(1): 1-9.

Soedijarto. 2004. Curriculum, Evaluation System, and Education Personnel as a Strategic Element in Organizing a National Teaching System. Jurnal Pendidikan Penabur.3 (3): 28-37.

Sudjimat, Dwi. A. 2014. Vocational Learning Planning. Malang: UM Press.

Sujati, H. 2015. Analisis Kebijakan Penataan Guru PNS. Prosiding Universitas PGRI Semarang 2015. $367-373$.

Sukmadinata, Nana Syaodih. 2013. Curriculum Development, Theory and Practice. Bandung: PT. Remaja Rosdakarya.

Sumarno, Wustqa \& Dhariva, Urwatul. 2014. Development of Learning Devices on High School Calculus Material Class XI. Jurnal Riset Pendidikan Matematika. 1(2): 257-267.

Toht, Peter. 2012. Learning Strategies and Style in Vocational Education. Acta Polytechnica Hungarica. 9 (3): 195-216.

Wagiran. 2007. Learning Innovation in the Preparation of the Future Workforce. Jurnal Pendidikan Teknologi \& Kejuruan. 16(1): 43-55.

Wen. 2003. Future of Education. Batam: Lucky Publishers. 